\title{
Properties of a store-operated nonselective cation channel in airway smooth muscle
}

\author{
P.B. Helli*,\# and L.J. Janssen*,\#
}

ABSTRACT: Passive depletion of internal $\mathrm{Ca}^{2+}$ stores in airway smooth muscle (ASM) activates nonselective cation channels (NSCCs) that mediate capacitative $\mathrm{Ca}^{2+}$ entry. However, the single channel properties of these cation channels have yet to be resolved and their regulation by cytosolic $\mathrm{Ca}^{2+}$ levels $\left(\left[\mathrm{Ca}^{2+}\right] i\right)$ still remains unclear.

NSCC currents and changes in $\left[\mathrm{Ca}^{2+}\right] i$ during passive depletion of internal $\mathrm{Ca}^{2+}$ stores were monitored in isolated bovine tracheal myocytes.

Loading cells with 1,2-bis(o-aminophenoxy)ethane- $N, N, N^{\prime}, N^{\prime}$-tetracetic acid acetyl methyl ester (BAPTA-AM) to reduce $\left[\mathrm{Ca}^{2+}\right] \mathrm{i}$ and thereby deplete the store augmented a basal $\mathrm{Gd}^{3+}-$ and $\mathrm{La}^{3+}-$ sensitive, $\mathrm{Ca}^{2+}$-permeable NSCC current. This current mimics that which is evoked by store depletion using the sarcoplasmic reticulum $\mathrm{Ca}^{2+}$ pump inhibitor cyclopiazonic acid (which concurrently and transiently elevates $\left.\left[\mathrm{Ca}^{2+}\right] i\right)$. Both interventions activated an $\sim 25-\mathrm{pS}$ NSCC with properties identical to both spontaneous (basal) and BAPTA-AM-evoked single channel currents.

In summary, the present study provides novel evidence that a lanthanide-sensitive, 25-pS nonselective cation channel underlies both basal and store depletion-evoked membrane currents in airway smooth muscle and that this conductance likely contributes to the regulation of resting $\left[\mathrm{Ca}^{2+}\right] i$ and capacitative $\mathrm{Ca}^{2+}$ entry.

KEYWORDS: Airway smooth muscle, BAPTA-AM, capacitative calcium entry, nonselective cation channel, single channel properties

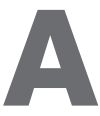
gonist-mediated bronchoconstriction involves release of $\mathrm{Ca}^{2+}$ from the sarcoplasmic reticulum (SR) [1-4]. The mechanisms responsible for store-refilling remain unclear but seem to include voltage-gated $\mathrm{Ca}^{2+}$ channels [5], nonselective cation channels (NSCCs) $[1,6,7]$ and/or reverse-mode $\mathrm{Na}^{+} / \mathrm{Ca}^{2+}$ exchange $[8,9]$. NSCCs formed by proteins of the transient receptor potential (TRP) family have received a great deal of attention, particularly those of the "canonical" or "classical" subtype (TRPC) [10-12].

In airway smooth muscle (ASM), evidence of a functional link between TRPC expression and enhanced $\mathrm{Ca}^{2+}$-influx (i.e. capacitative $\mathrm{Ca}^{2+}$ entry (CCE)) remains sparse. Recently, WHITE et al. [10] demonstrated that disruption of endogenous TRPC3 expression in human ASM reduced both resting cytosolic $\mathrm{Ca}^{2+}$ concentration $\left(\left[\mathrm{Ca}^{2+}\right] i\right)$ and $\mathrm{CCE}$; indirect pharmacological data suggested involvement of a NSCC but membrane currents were not measured directly. Indeed, only a few studies have directly examined store depletionevoked membrane currents in ASM [1, 7, 13]. Hence, it is not surprising that their single channel properties have yet to be resolved.
In addition, many previous studies of CCE were performed in the presence of agents which release stored $\mathrm{Ca}^{2+}$ (e.g. inositol triphosphate, caffeine) and/or which inhibit $\mathrm{Ca}^{2+}$ reuptake by the SR $\mathrm{Ca}^{2+}$ ATPase (SERCA; e.g. cyclopiazonic acid (CPA), thapsigargin) [7, 14-17]. However, these approaches elevate $\left[\mathrm{Ca}^{2+}\right] i[4,14]$, which calls into question whether these currents are store depletion-activated or merely $\mathrm{Ca}^{2+}$ dependent since ASM is known to express NSCCs that are facilitated by elevated $\left[\mathrm{Ca}^{2+}\right] i[2,6,18]$; in fact, currents by CPA in isolated bovine tracheal smooth muscle (TSM) cells paralleled the transient increase in $\left[\mathrm{Ca}^{2+}\right] i[7]$.

In order to better understand the relationship between store depletion, activation of NSCCs and regulation of $\left[\mathrm{Ca}^{2+}\right] i$ in ASM, activation of NSCC current during SR-depletion by loading the cells with the $\mathrm{Ca}^{2+}$ chelator 1,2-bis(o-aminophenoxy)ethane- $N, N, N^{\prime}, N^{\prime}$-tetracetic acid acetyl methyl ester (BAPTA-AM) was compared with inhibiting SERCA with CPA. The single channel properties of this conductance were also probed, as well as the contribution of this and other $\mathrm{Ca}^{2+}$ permeable channels in mediating $\mathrm{Ca}^{2+}$ entry the time course of activation of whole-cell NSCC
AFFILIATIONS

*Dept of Medicine, McMaster

University, and

"Firestone Institute for Respiratory Health, St. Joseph's Healthcare, Hamilton, ON, Canada.

CORRESPONDENCE

L.J. Janssen

St. Joseph's Hospital

room L314

50 Charlton Avenue East

Hamilton

ON

Canada

L8N 4A6

Fax: 19055406510

E-mail: janssenl@mcmaster.ca

Received:

April 092008

Accepted after revision:

June 262008

SUPPORT STATEMENT

These studies were supported by operating grants and a Career Award (L.J. Janssen) from the Canadian Institutes of Health Research (MOP 15561) and the Ontario Thoracic Society.

STATEMENT OF INTEREST Statements of interest for both authors can be found at www.erj.ersjournals.com/misc/ statements.shtml 
upon SR $\mathrm{Ca}^{2+}$ depletion. Here, the present authors report that depletion of SR $\mathrm{Ca}^{2+}$ stores in the presence or absence of cytosolic $\mathrm{Ca}^{2+}$ transients activates an $\sim 25-\mathrm{pS}$ NSCC that contributes to resting $\left[\mathrm{Ca}^{2+}\right] i, \mathrm{CCE}$ and likely functions to refill internal $\mathrm{Ca}^{2+}$ stores in ASM.

\section{MATERIALS AND METHODS \\ Tissues}

All experimental procedures were approved by the McMaster University Animal Care Committee (McMaster University, Hamilton, ON, Canada) and conform to the guidelines set out by the Canadian Council on Animal Care (Ottawa, ON, Canada).

Trachea from commercial cattle (136-454 kg) were obtained at a local abattoir and transported in ice-cold Krebs' solution containing $116 \mathrm{mM} \mathrm{NaCl}, 4.6 \mathrm{mM} \mathrm{KCl}, 2.5 \mathrm{mM} \mathrm{CaCl}_{2}, 1.3 \mathrm{mM}$ $\mathrm{NaH}_{2} \mathrm{PO}_{4}, 1.2 \mathrm{mM} \mathrm{MgSO}_{4}, 23 \mathrm{mM} \mathrm{NaHCO}, 11 \mathrm{mM}$ dextrose and $0.01 \mathrm{mM}$ indomethacin, bubbled with $95 \% \mathrm{O}_{2} / 5 \% \mathrm{CO}_{2}$ in order to maintain a $\mathrm{pH}$ of 7.4. ASM was dissected free of epithelium and connective tissue and maintained in Krebs solution at $4^{\circ} \mathrm{C}$ for up to $48 \mathrm{~h}$.

\section{Cell isolation}

Bovine TSM strips were gently agitated for 20 mins in modified Hank's balanced salt solution (with $\mathrm{NaHCO}_{3}$, without $\mathrm{CaCl}_{2}$ and $\mathrm{MgSO}_{4}$ ) containing $2 \mathrm{mg} \cdot \mathrm{mL}^{-1}$ collagenase (Sigma blend type-F; Sigma-Aldrich, Oakville, ON, Canada) and $250 \mu \mathrm{g} \cdot \mathrm{mL}^{-1}$ elastase (type-IV) at room temperature (21$23^{\circ} \mathrm{C}$ ), then for an additional $20-40 \mathrm{mins}$ at $37^{\circ} \mathrm{C}$. Cells were dispersed by gentle trituration with a wide-bore pipette, centrifuged and resuspended in standard Ringer's solution containing $130 \mathrm{mM} \mathrm{NaCl}, 5 \mathrm{mM} \mathrm{KCl}, 1 \mathrm{mM} \mathrm{CaCl}, 1 \mathrm{mM}$ $\mathrm{MgCl}_{2}, 20 \mathrm{mM}$ HEPES, $10 \mathrm{mM}$ dextrose and $0.1 \mathrm{mM}$ niflumic acid (omitted for $\mathrm{Ca}^{2+}$ imaging) and adjusted to $\mathrm{pH} 7.4$ with $\mathrm{NaOH}$.

\section{Electrophysiology}

Single cells were allowed to adhere to the bottom of a recording chamber (1.5-mL volume) and then superfused with standard Ringer's solution at room temperature $\left(21-23^{\circ} \mathrm{C}\right)$. Electrophysiological responses were tested in cells that were phase-dense and appeared relaxed. Average cell capacitance was $59 \pm 5 \mathrm{pF}(\mathrm{n}=13)$.

Whole-cell currents were studied using the nystatin perforated patch configuration of the standard patch-clamp technique. Pipettes with tip resistances of 3-5 M $\Omega$ were fashioned from borosilicate glass. Tip potentials were nulled and electrophysiological recordings commenced, once series resistance dropped below $30 \mathrm{M} \Omega ; 70-80 \%$ compensation was routinely employed. A holding potential of $0 \mathrm{mV}$ was used to inactivate voltage-gated $\mathrm{Ca}^{2+}$ channels. Whole-cell currents were lowpass filtered at $1 \mathrm{kHz}$, sampled and digitised at $2.5 \mathrm{kHz}$ (DigiData 1200 A/D converter; Axon Instruments, Foster City, CA, USA).

Liquid junction potentials between the electrode and bathing solutions were $3.5 \pm 0.3(n=6)$ and $11 \pm 0.3 \mathrm{mV}(n=4)$ for standard Ringer's and $\mathrm{Na}^{+}$-free Ringer's solution, respectively; reversal potentials $(\mathrm{Er})$ shown in the figures are not corrected whereas elsewhere they are corrected as previously described [7].
Pipettes with tip resistances of 7-13 Mohm were used to record single channel currents from on-cell patches. These currents were filtered at $5 \mathrm{kHz}$, sampled and digitised (at $20 \mathrm{kHz}$ ), and stored directly on a local hard-drive. Membrane potential was set to $0 \mathrm{mV}$ by superfusing cells with a high molar $\mathrm{KCl}$ solution (see Solutions and Chemicals section). For offline analysis and figure preparation, single channel currents were filtered at $500 \mathrm{~Hz}$. To evaluate single channel current--voltage (I-V) characteristics, membrane potential was manually stepped from -120 to $60 \mathrm{mV}$. The transmembrane potential $(\mathrm{Vm})$ is described by the equation:

$$
\mathrm{Vm}=\mathrm{V}_{\text {cell }}-\mathrm{V}_{\text {pipette }}
$$

where $V_{\text {cell }}$ is the membrane potential of the cell and $V_{\text {pipette is }}$ the potential imposed by the recording pipette. Assuming Vcell has been set to $0 \mathrm{mV}$ by the external $\mathrm{KCl}$ solution, $\mathrm{Vm}$ is the negative of Vpipette. Inward channel currents are shown as downward deflections while outward currents are shown as upward deflections.

\section{$\left[\mathrm{Ca}^{2+}\right]$ i fluorimetry}

Single cells were incubated with fluo-4 AM ( $2 \mu \mathrm{M}$; containing $0.1 \%$ pluronic $\mathrm{F}-127$ ) for $30 \mathrm{~min}$ at $37^{\circ} \mathrm{C}$, then placed in a Plexiglas ${ }_{\circledast}$ recording chamber and superfused with Ringer's solution for 30 mins to allow for dye de-esterification. Confocal microscopy was performed at room temperature $\left(21-23^{\circ} \mathrm{C}\right)$ as previously described [7]. Video images $(600 \times 400$ pixels; Video Savant 4.0; IO Industries, London, ON, Canada) were generated at 1 frame $\cdot \mathrm{s}^{-1}$ for caffeine responses and 0.1 frame $\cdot \mathrm{s}^{-1}$ for all other responses. Average fluorescence intensities from regions of interest $(30 \times 30$ pixels $)$ defined in central non-nuclear regions of cells were calculated for each frame and plotted against time. Relative changes in $\left[\mathrm{Ca}^{2+}\right]$ were expressed in terms of a change in fluorescence $(\Delta \mathrm{F})$ over the initial/baseline fluorescence $\left(\mathrm{F}_{0}\right)$ observed in the presence of $1.8 \mathrm{mM}$ extracellular $\mathrm{Ca}^{2+}$. Caffeine was applied directly to cells via pipette driven by a pressure ejection system (Picospritzer ${ }^{\mathrm{TM}}$ II; General Valve, Fairfield, NJ, USA).

\section{Solutions and chemicals}

All drugs and reagents were obtained from Sigma-Aldrich (Oakville, ON, Canada). $\mathrm{Ca}^{2+}$-free Ringer's contained $130 \mathrm{mM} \mathrm{NaCl}, 5 \mathrm{mM} \mathrm{KCl}, 1 \mathrm{mM} \mathrm{MgCl}_{2}, 20 \mathrm{mM}$ HEPES, $10 \mathrm{mM}$ dextrose, $0.01 \mathrm{mM}$ EGTA and $0.1 \mathrm{mM}$ niflumic acid (omitted for $\mathrm{Ca}^{2+}$-imaging), adjusted to $\mathrm{pH} 7.4$ with $\mathrm{NaOH}$. $\mathrm{Na}^{+}$-free Ringer's solution consisted of $140 \mathrm{mM} \mathrm{N}$-methyl-Dglucamine (NMDG), $5 \mathrm{mM} \mathrm{KCl}, 1 \mathrm{mM} \mathrm{CaCl}, 1 \mathrm{mM} \mathrm{MgCl}$, $10 \mathrm{mM}$ HEPES (adjusted to pH 7.4 with $\mathrm{NaOH}$ ), $10 \mathrm{mM}$ dextrose and $0.1 \mathrm{mM}$ niflumic acid, adjusted to $\mathrm{pH} 7.4$ with $\mathrm{HCl}$. High molar $\mathrm{KCl}$ Ringer's solution contained $126 \mathrm{mM}$ $\mathrm{KCl}, 1.5 \mathrm{mM} \mathrm{CaCl}, 1 \mathrm{mM} \mathrm{MgCl}$, $10 \mathrm{mM}$ HEPES, $10 \mathrm{mM}$ dextrose and $0.1 \mathrm{mM}$ niflumic acid adjusted to $\mathrm{pH} 7.4$ with $\mathrm{NaOH}$.

The intracellular electrode solution for measuring whole-cell currents contained $130 \mathrm{mM} \mathrm{CsCl}, 5 \mathrm{mM} \mathrm{MgCl}, 1 \mathrm{mM} \mathrm{CaCl}_{2}$, $10 \mathrm{mM}$ HEPES and $5 \mathrm{mM}$ EGTA, adjusted to $\mathrm{pH} 7.2$ with $\mathrm{CsOH}$. These pharmacological and ionic conditions eliminated currents through $\mathrm{Ca}^{2+}$-dependent $\mathrm{Cl}^{-}$and $\mathrm{K}^{+}$channels. The standard electrode solution for on-cell recordings consisted of $126 \mathrm{mM} \mathrm{NaCl}, 1.5 \mathrm{mM} \mathrm{CaCl}_{2}, 10 \mathrm{mM} \mathrm{HEPES}$ and $10 \mathrm{mM}$ 
a)

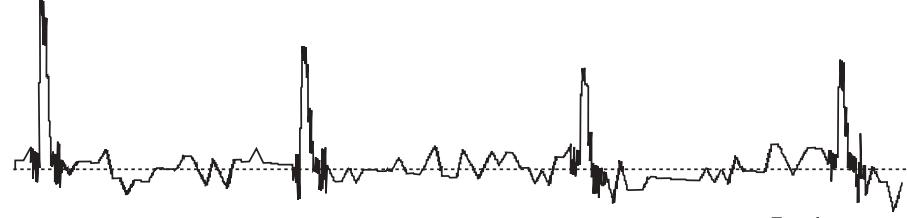

\#

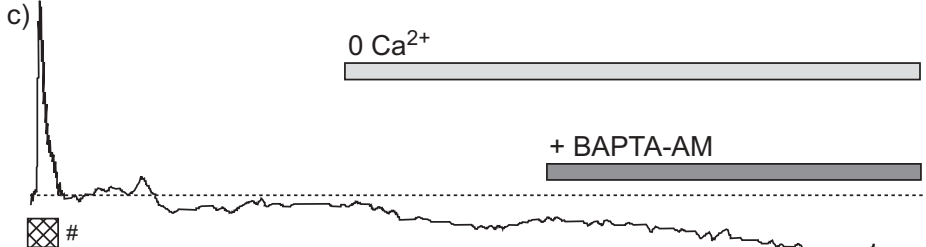

b)

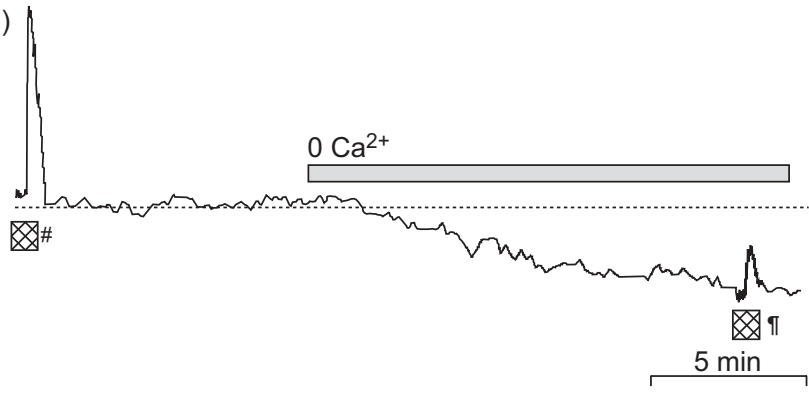

d)

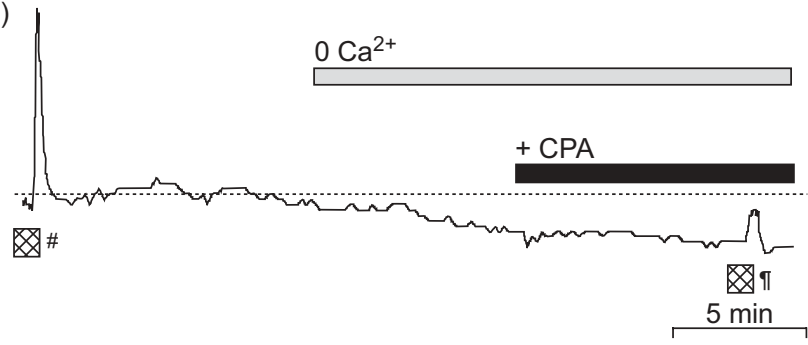

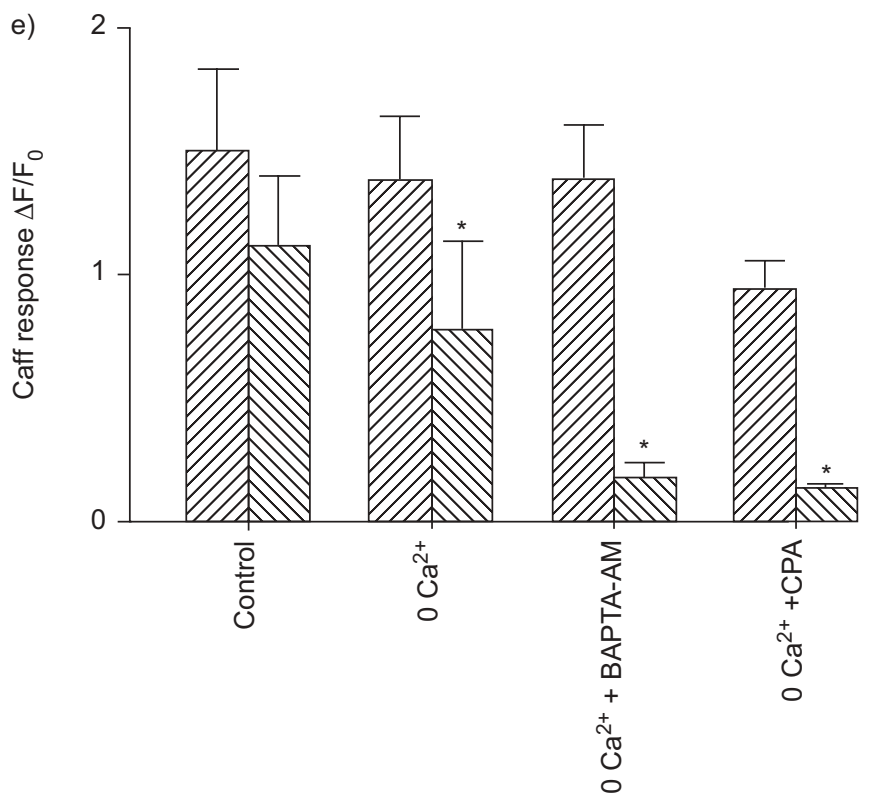

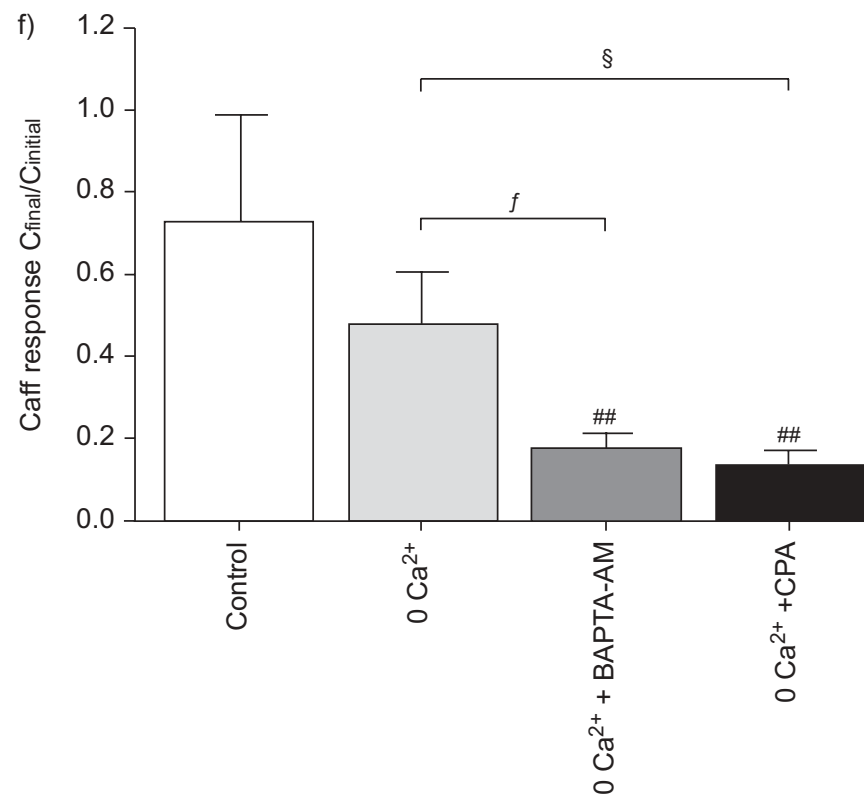

FIGURE 1. Effect of store depletion on cytosolic $\mathrm{Ca}^{2+}$ and sarcoplasmic reticulum $\mathrm{Ca}^{2+}$ concentration. a-d) representative fluorimetric traces illustrating effects of removal of extracellular $\mathrm{Ca}^{2+}\left(0 \mathrm{Ca}^{2+} ; \square\right)$, with or without concurrent treatment with: c) $10 \mu \mathrm{M}$ BAPTA-AM ( $\left.\square\right)$ or d) $10 \mu \mathrm{M}$ cyclopiazonic acid (CPA) on cytosolic Ca ${ }^{2+}$ concentration transients evoked by $10 \mathrm{mM}$ caffeine (10 s application; $)$. Caffeine (caff) response mean data expressed both as: e) Change in fluorescence ( $\Delta \mathrm{F}) / \mathrm{baseline}$ fluorescence $\left(F_{0}\right)$ at initial response to caffeine (Cinitial; $\mathbb{Z} ;{ }^{*}{ }^{*}$ in a-d) and final response (Cfinal; $\mathbb{\mathbb { N }} ;{ }^{\circledR}$ in a-d) and f) Cfinal/Cinitial for control cells $(n=10), 0$ Ca ${ }^{2+}(n=9), 0$ Ca ${ }^{2+}+$ BAPTA-AM $(n=10)$ and $0 \mathrm{Ca}^{2+}+$ CPA $(n=8) . \cdots \cdot 0 .{ }^{*}: p<0.05$ versus initial response in same group, paired two-tailed t-test; ${ }^{\# \#}: p<0.05$ in a one-way ANOVA versus control. s: $p=0.028 ;$; $: p=0.03$.

dextrose, adjusted to $\mathrm{pH} 7.4$ with $\mathrm{NaOH}$. For high-Ca ${ }^{2+}$ electrode solution, $\mathrm{NaCl}$ was replaced by $70 \mathrm{mM} \mathrm{CaCl}$. All on-cell electrode solutions were supplemented with $10 \mathrm{mM}$ tetraethylammonium chloride, $5 \mathrm{mM}$ 4-aminopyridine, $100 \mu \mathrm{M}$ niflumic acid and $1 \mu \mathrm{M}$ nifedipine to inhibit $\mathrm{K}^{+}-, \mathrm{Cl}^{-}-$ and voltage-gated $\mathrm{Ca}^{2+}$ channels.

Nystatin for whole cell recordings was prepared in dimethyl sulphoxide (DMSO; $30 \mathrm{mg} \cdot \mathrm{mL}^{-1}$ ) for storage up to 5 days, and diluted to a final concentration of $300 \mu \mathrm{g} \cdot \mathrm{mL}^{-1}$ in electrode solution daily. Reagents were dissolved in aqueous media (for
$\mathrm{Gd}^{3+}, \mathrm{La}^{3+}$, caffeine) or DMSO (for CPA, BAPTA-AM, fluo-4 AM, nifedipine); the final concentration of DMSO in the bath was $\leqslant 0.001 \%$ in all cases.

\section{Data analysis}

Whole-cell current records were obtained immediately before and during drug application with each cell acting as its own control. In studies where channel inhibitors were used, data are reported as \% inhibition of BAPTA-AM evoked current prior to subtraction of baseline current. 

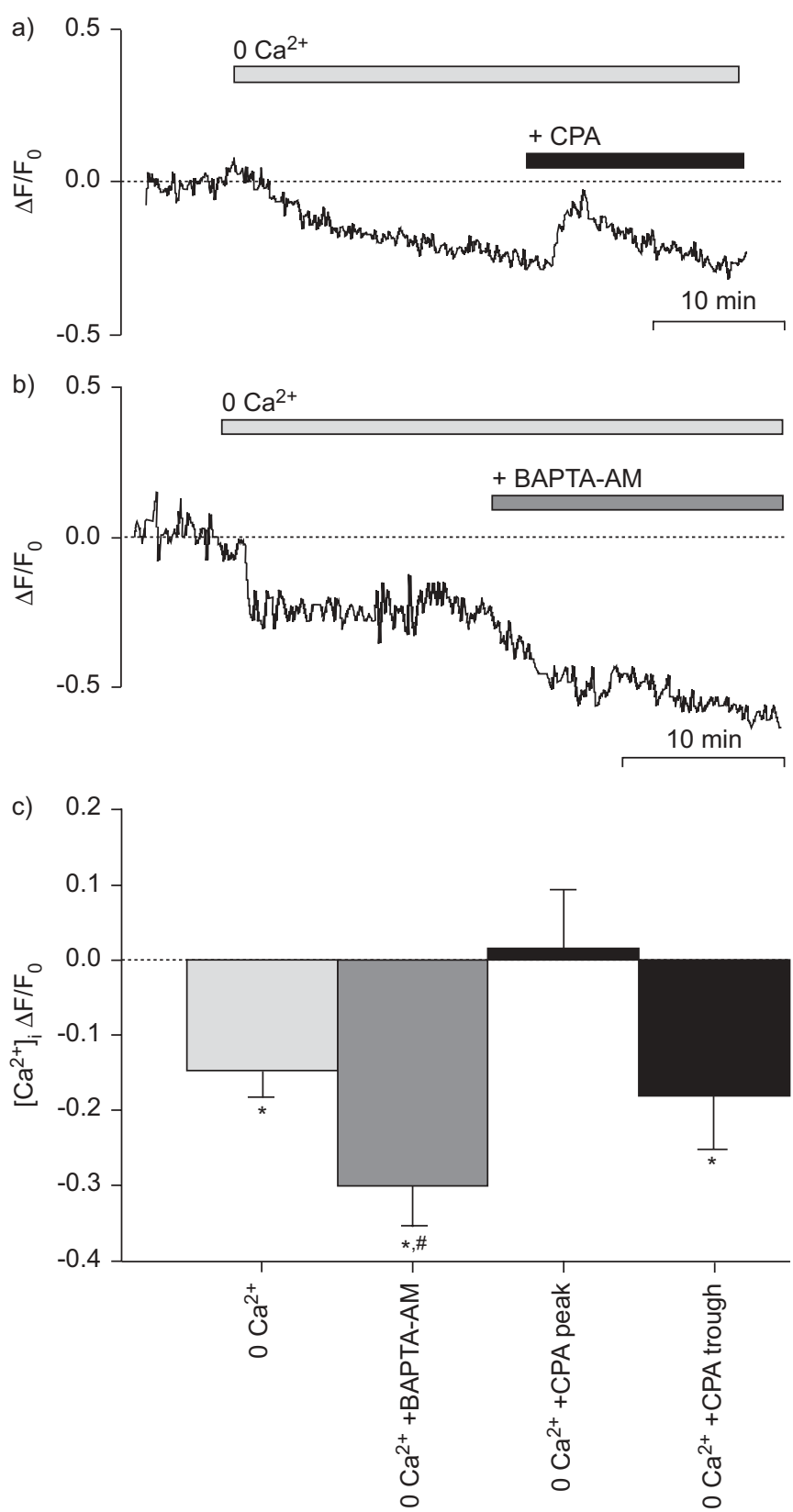

FIGURE 2. Representative traces illustrating changes in cytosolic $\mathrm{Ca}^{2+}$ concentration $\left[\mathrm{Ca}^{2+}\right] i$ following removal of extracellular $\mathrm{Ca}^{2+}\left(0 \mathrm{Ca}^{2+} ;{ }^{-1}\right)$ followed by inhibition of the sarcoplasmic reticulum $\mathrm{Ca}^{2+}$ ATPase with $10 \mu \mathrm{M}$ cyclopiazonic acid (CPA) or passive loading with $10 \mu \mathrm{M}$ BAPTA-AM in bath. c) mean change in $\left[\mathrm{Ca}^{2+}\right] i(\mathrm{n}=12-35), \cdots: 0 .{ }^{*}: \mathrm{p}<0.05$, change in $\left[\mathrm{Ca}^{2+}\right] i$ from baseline $\left(\mathrm{F}_{0}\right)$. \#: $\mathrm{p}<0.05$ versus $0 \mathrm{Ca}^{2+}$, one-way ANOVA.

Unitary current amplitude histograms for individual patches were constructed from $0.5-2-\mathrm{s}$ sections of raw traces. I-V relationships, from individual patches in which unitary channel current amplitudes were measured at a minimum of three different membrane potentials, were plotted and the unitary conductance and Er for individual patches were then calculated using linear regression (least-squares method). The mean unitary conductance and $\mathrm{Er}$ were determined by averaging values from individual patches.
All data are reported as means \pm SEM, $n$ values indicate number of animals tested; comparisons were made using a paired or unpaired t-test or one-way ANOVA as appropriate, with pvalues $<0.05$ considered significant.

\section{RESULTS}

\section{Differential effects of store depletion protocols on $\left[\mathrm{Ca}^{2+}\right] \mathrm{i}$} and $\mathrm{SR} \mathrm{Ca}^{2+}$ content

$\left[\mathrm{Ca}^{2+}\right]$ i responses evoked by a $10-\mathrm{s}$ application of $10 \mathrm{mM}$ caffeine were utilised as an index of SR $\mathrm{Ca}^{2+}$ content. In the presence of $1.8 \mathrm{mM}$ extracellular $\mathrm{Ca}^{2+}$, repetitive caffeine stimulations at 5-min intervals evoked reproducible transient $\left[\mathrm{Ca}^{2+}\right]$ i elevations (fig. $1 \mathrm{a}-\mathrm{d}$ ). In contrast, bathing cells in $\mathrm{Ca}^{2+}$ free Ringer's solution for 10 mins, reduced baseline $\left[\mathrm{Ca}^{2+}\right]$ $\left(\Delta \mathrm{F} / \mathrm{F}_{0}=-15 \pm 3, \mathrm{n}=35 ; \mathrm{p}<0.001\right)$ and decreased the magnitude of caffeine-evoked transients by $52 \pm 13 \% \quad(n=9 ; p=0.027)$, suggesting that basal $\mathrm{Ca}^{2+}$ entry is necessary for the maintenance of resting $\left[\mathrm{Ca}^{2+}\right] i$ and $\mathrm{SR} \mathrm{Ca}^{2+}$ loading. L-type $\mathrm{Ca}^{2+}$ channels did not mediate this basal $\mathrm{Ca}^{2+}$ entry, since $1 \mu \mathrm{M}$ nifedipine did not significantly reduce baseline fluorescence $\left(\Delta \mathrm{F} / \mathrm{F}_{0}=0.6 \pm 0.6, \mathrm{n}=10\right.$, data not shown).

Both CPA and BAPTA-AM (10 $\mu \mathrm{M}$ each) further reduced SR $\mathrm{Ca}^{2+}$ content such that caffeine-evoked $\left[\mathrm{Ca}^{2+}\right]$ i responses were reduced to a much greater extent than was seen following removal of extracellular $\mathrm{Ca}^{2+}$ alone (fig. 1a-d). In the absence of extracellular $\mathrm{Ca}^{2+}$, application of CPA evoked a transient rise in fluorescence, followed within 10 mins by a sustained decrease to pre-drug levels (fig. 2); the rise in $\left[\mathrm{Ca}^{2+}\right]$ i likely reflecting $\mathrm{Ca}^{2+}$ leak from the SR via ryanodine receptors, while the return to baseline involves $\mathrm{Ca}^{2+}$ extrusion via the plasmalemmal $\mathrm{Ca}^{2+}$ pump $[4,5,14,19]$. In contrast, treating cells with BAPTA-AM following removal of external $\mathrm{Ca}^{2+}$ caused a further decline in $\left[\mathrm{Ca}^{2+}\right] i$ that stabilised within 10 15 mins (fig. 2).

\section{Loading with BAPTA-AM activates a NSCC in bovine TSM cells}

In cells held under voltage-clamp, a small membrane current with mean amplitude of $-82 \pm 19 \mathrm{pA}$ at $-60 \mathrm{mV}$ was observed. BAPTA-AM markedly increased the amplitude of this current, which was stable for $>30$ mins (fig. 3). Voltage steps from $-80 \mathrm{mV}$ to $60 \mathrm{mV}$ (10 $\mathrm{mV}$ increments, $200 \mathrm{~ms}$ duration, from a holding potential of $0 \mathrm{mV}$ ) elicited currents that showed little time-dependent activation except at very negative potentials and no deactivation over the $200 \mathrm{~ms}$ period of the voltage step (fig. 3). The steady-state I-V relationship of both the baseline membrane current and BAPTA-AM-evoked current were linear with $\mathrm{Er}$ of $5.4 \pm 2.2$ and $-1.5 \pm 1.5 \mathrm{mV}$ respectively $(\mathrm{n}=14$; fig. 3). Instantaneous $\mathrm{I}-\mathrm{Vs}$ obtained using ramp voltage commands (-100 to $80 \mathrm{mV}$, 2-s duration, from a holding potential of $0 \mathrm{mV}$ ) were identical ( $c f$. fig. $4 \mathrm{~d}$ ).

Replacement of extracellular $\mathrm{Na}^{+}$with NMDG substantially reduced the inward portion of the BAPTA-AM-dependent current (fig. 4) such that the I-V relationship was best described by a quadratic equation and Er was displaced from $-3.8 \pm 2.4 \mathrm{mV}$ to $-21 \pm 1.2 \mathrm{mV}(\mathrm{n}=4)$, representing a shift of $-17 \mathrm{mV}(95 \%$ confidence interval (CI) of $-13--21 \mathrm{mV})$ as would be expected if $\mathrm{Na}^{+}$were a major charge carrier for this conductance. 

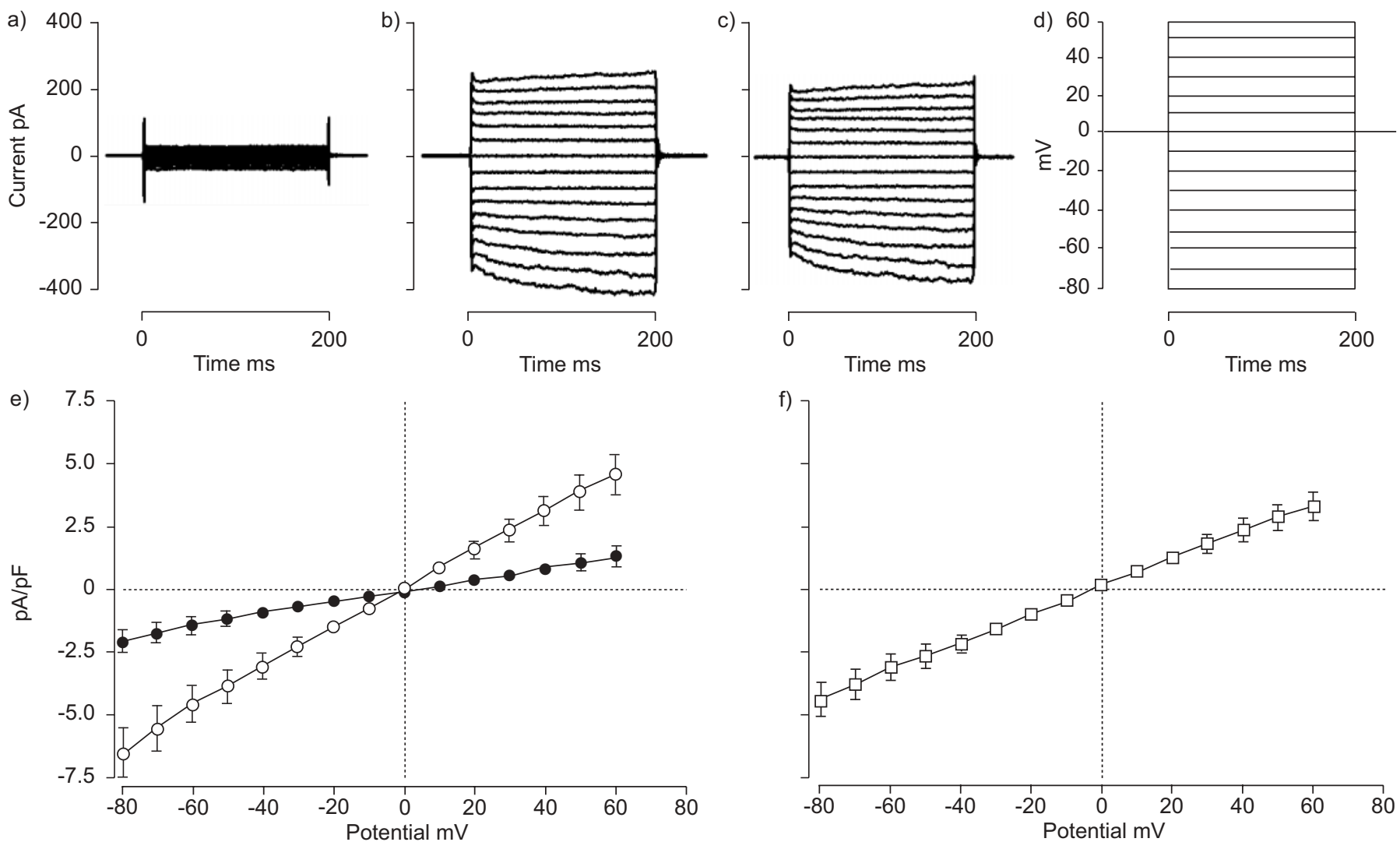

FIGURE 3. Store depletion by BAPTA-AM augments a basal nonselective cation channel current. Representative traces of membrane currents evoked by voltage step pulses (200 ms duration, $10 \mathrm{mV}$ increments as shown in d) delivered from a holding potential of $0 \mathrm{mV}$ before (a) and after (b) application of $10 \mu \mathrm{M}$ BAPTA-AM; the difference in current is also shown (c). e) Mean currents obtained prior to $(\bullet)$ and during application of BAPTA-AM $(O ; n=13)$. f) Difference ( $\square$ ) between before and during application of BAPTA-AM. …: 0 .

Next, the pharmacology of the BAPTA-AM-activated current in these cells was examined by addition of blockers to the bathing medium (results summarised in table 1 ). $\mathrm{La}^{3+}$, which inhibits CCE in several ASM preparations [10, 16, 20], reduced BAPTA-AM-evoked membrane currents but did not shift Er (fig. 5); this effect was concentration dependent and poorly reversible. Alternatively, $10 \mu \mathrm{M} \mathrm{Gd}^{3+}$ (which has been widely utilised as an inhibitor of NSCCs and CCE in several smooth muscle cell types [21-23]) had little effect on the BAPTA-AMevoked current, although $100 \mu \mathrm{M}$ caused a marked and irreversible suppression (fig. 5).

\section{Cell attached patches exhibit spontaneous single channel activity}

In order to better understand the nature of the channel responsible for mediating resting and store-depletion evoked whole-cell membrane currents in bovine TSM cells, single channel events recorded from cell-attached patches were examined. Using high- $\mathrm{K}^{+}$Ringer's solution to clamp $\mathrm{Vm}$ around $0 \mathrm{mV}$ and a pipette solution containing $126 \mathrm{mM} \mathrm{NaCl}$ and $1.5 \mathrm{mM} \mathrm{Ca}^{2+}$, discrete single channel openings were recorded at both positive and negative transmembrane potentials (fig. 6a). In eight of the 18 cells examined, these spontaneous events were sufficiently frequent to allow for analysis of unitary current amplitudes; the I-V relationship of the spontaneous single channel currents had a slope-conductance of $26 \pm 0.3 \mathrm{pS}$ with
$\mathrm{Er}=-2 \pm 3 \mathrm{mV}(\mathrm{n}=4$; fig. 6e). When studied with a patch pipette containing $70 \mathrm{mM} \mathrm{CaCl}_{2}$ the slope conductance was unchanged $(24 \pm 2 \mathrm{pS})$ but the Er was shifted leftward $-14 \mathrm{mV}(\mathrm{p}=0.024$, $\mathrm{n}=4$; fig. 6e), indicative of a high permeability to $\mathrm{Na}^{+}$.

\section{CPA and BAPTA-AM evoke single channel activity in previously quiescent patches}

In membrane patches exhibiting little evidence of spontaneous single channel activity, treatment with $10 \mu \mathrm{M} \mathrm{CPA}$ or $10 \mu \mathrm{M}$ BAPTA-AM substantially increased the number of single channel events (figs 7 and 8). The I-V relationships for these unitary events were linear in nature, with a slope-conductance of $23 \pm 1$ and $26 \pm 1 \mathrm{pS}$ and Er occurring at $-5 \pm 3$ and $-6 \pm 1 \mathrm{mV}$ for CPA $(n=7)$ and BAPTA-AM $(n=3)$, respectively $(126 \mathrm{mM}$ $\mathrm{NaCl}$ electrode and $140 \mathrm{mM} \mathrm{KCl}$ bathing solution; fig. 8). When studied with a $70 \mathrm{mM} \mathrm{CaCl} 2$ pipette solution, the slope conductance and Er of the CPA-evoked single channel current was $20 \pm 1 \mathrm{pS}$ and $-10 \pm 5 \mathrm{mV}(\mathrm{n}=3)$, respectively. The similarities in the properties of the spontaneous, CPA- and BAPTAAM-evoked single channel currents, as well as the similarity of their I-V relationship with that of the whole cell current, suggests that the same NSCC underlies all three.

\section{DISCUSSION}

In many smooth muscle cell types, agonists release $\mathrm{Ca}^{2+}$ from an intracellular $\mathrm{Ca}^{2+}$ store $[6,16,23]$. Subsequent restoration of 


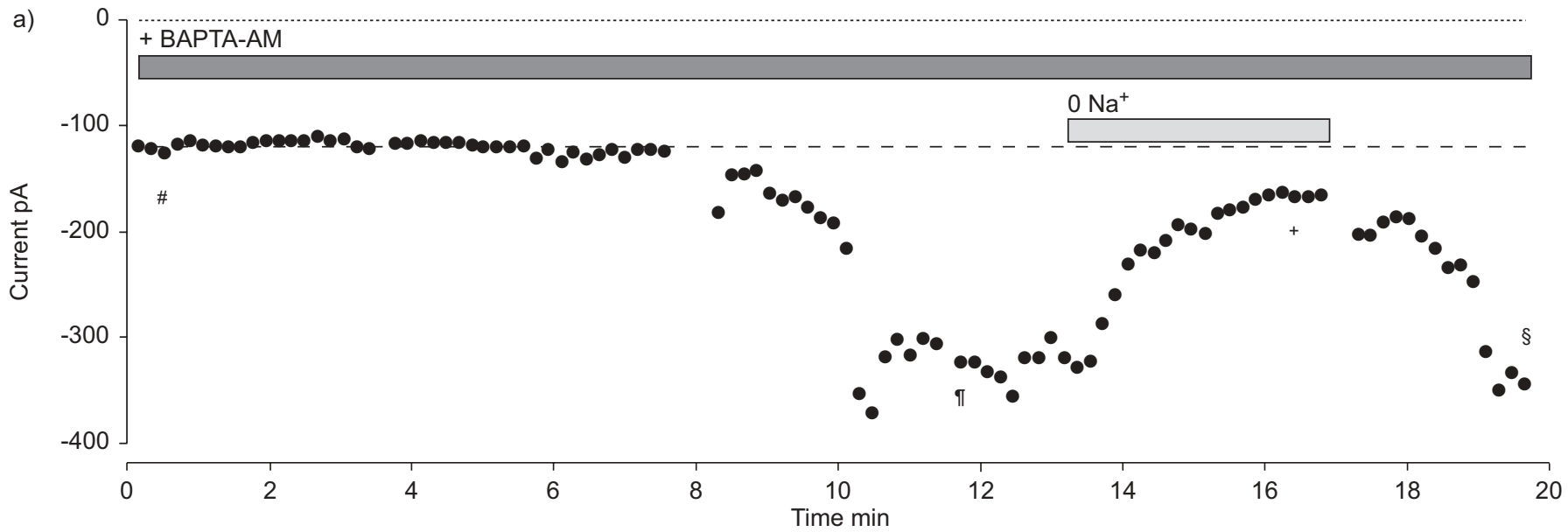

b)

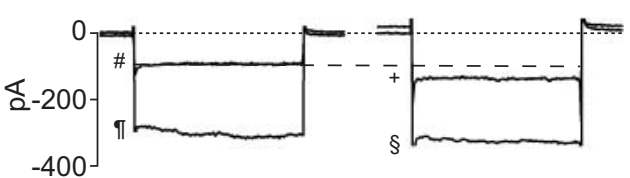

c)

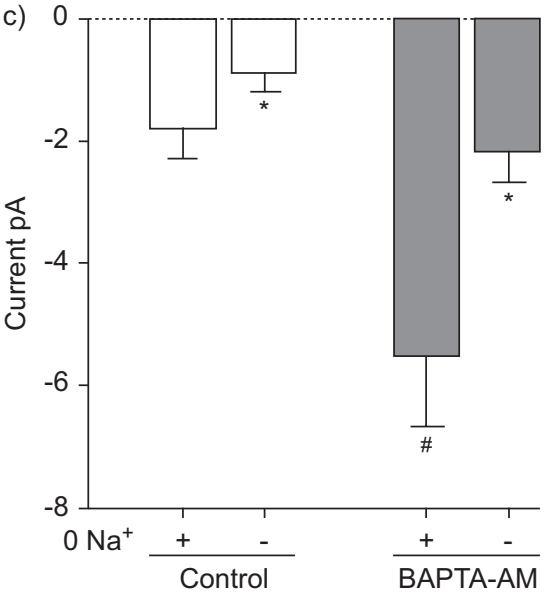

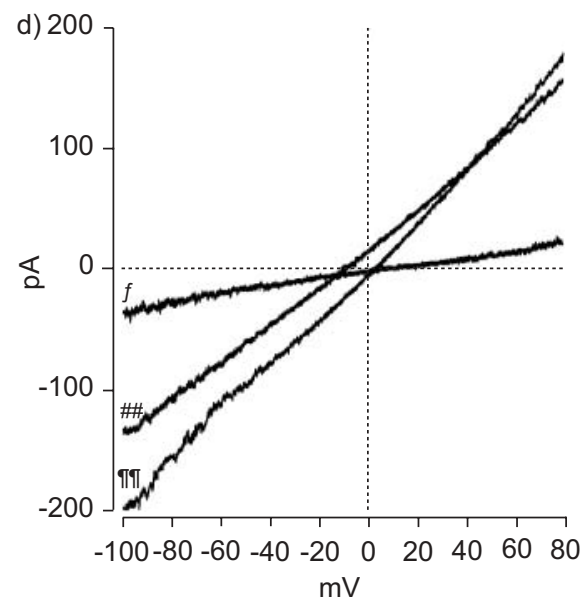

FIGURE 4. Effect of removing external $\mathrm{Na}^{+}$on basal and BAPTA-AM-evoked nonselective cation channel currents. a) time course of BAPTA-AM-evoked ( $\square$ ) whole-cell current. Mean current (-) observed upon voltage stepping cell to -60 mV from a holding potential of $0 \mathrm{mV}$ (200 ms duration, $10 \mathrm{~s}$ intervals). Extracellular $\mathrm{Na}^{+}$in the bathing medium (flow rate of $\sim 3 \mathrm{~mL} \cdot \mathrm{min}^{-1}$ ) was replaced with equimolar $\mathrm{N}$-methyl-D-glucamine (NMDG; - ). b) current traces from the cell shown in a at time-points ${ }^{\#}$, $"{ }^{+}{ }^{+}$and ${ }^{\S}$. c) mean basal $(\square, n=5)$ and BAPTA-AM-evoked $(\square, n=4)$ current at $-60 \mathrm{mV}$ before $(-)$ and after $(+)$ replacement of extracellular $\mathrm{Na}^{+}\left(0 \mathrm{Na}^{+}\right)$. d) basal $\left({ }^{f}\right)$ and BAPTA-AMevoked membrane currents in the presence of $\mathrm{Na}^{+}\left({ }^{\text {"* }}\right.$ ) or following replacement with NMDG (\#) obtained from a single cell studied using a voltage ramp from -100 mV to $80 \mathrm{mV}$ over $2 \mathrm{~s} . \cdots \cdot$; ; -----: basal current. *: $\mathrm{p}<0.05$ reduction upon removal of $\mathrm{Na}^{+} ;{ }^{*}: \mathrm{p}<0.05$, one-way ANOVA versus control.

$\left[\mathrm{Ca}^{2+}\right] i$ includes both re-uptake into the store by SERCA as well as extrusion from the cell by the plasmalemmal $\mathrm{Ca}^{2+}$ pump and/or $\mathrm{Na}^{+} / \mathrm{Ca}^{2+}$ exchanger. As such, there must be

\section{TABLE 1 Pharmacological profile of BAPTA-AM-evoked membrane current in bovine tracheal smooth muscle cells measured at $-60 \mathrm{mV}$.}

\begin{tabular}{ccc} 
Inhibitor & $\begin{array}{c}\text { BAPTA-AM-evoked current inhibition } \\
\%\end{array}$ & $\mathbf{n}$ \\
\hline $\begin{array}{c}\mathbf{G d}^{3+} \\
10 \mu \mathrm{M}\end{array}$ & \\
$100 \mu \mathrm{M}$ & $35 \pm 15$ & 6 \\
$\mathrm{La}^{3+}$ & $80 \pm 5^{\star}$ & 6 \\
$1 \mu \mathrm{M}$ & $28 \pm 15$ & \\
$10 \mu \mathrm{M}$ & $65 \pm 8^{\star}$ & 4 \\
$100 \mu \mathrm{M}$ & $82 \pm 3^{\star}$ & 5 \\
\hline
\end{tabular}

Data are presented as mean \pm SEM. *: $p<0.05$ from one-tailed paired t-test. mechanisms in place to compensate for the net loss of cellular $\mathrm{Ca}^{2+}$ in order to avoid complete depletion of the store. In ASM, it appears that CCE, mediated by NSCCs, may be involved $[1,5,7,13]$; however there are many unresolved issues regarding the electrophysiological properties, regulation and physiological roles of these channels. The present study examined the properties of a membrane conductance activated by store depletion through either chelation of intracellular $\mathrm{Ca}^{2+}$ with BAPTA or inhibition of SERCA with CPA. In addition, the relative contribution of this channel in regulating $\left[\mathrm{Ca}^{2+}\right] i$ and CCE was also examined, with the goal of generating a better understanding of the ionic mechanisms underlying CCE in ASM. Notably, novel data regarding the single channel characteristics of this conductance are presented.

Many of the isolated bovine TSM cells displayed NSCC currents at rest (i.e., prior to store depletion); this has been described previously [7]. NSCCs in ASM, whether activated by G-protein coupled receptor stimulation [6] or by passive depletion of SR $\mathrm{Ca}^{2+}$ (present study and [7]), are highly permeable to $\mathrm{Na}^{+}$, conducting a significant inward $\mathrm{Na}^{+}$current 

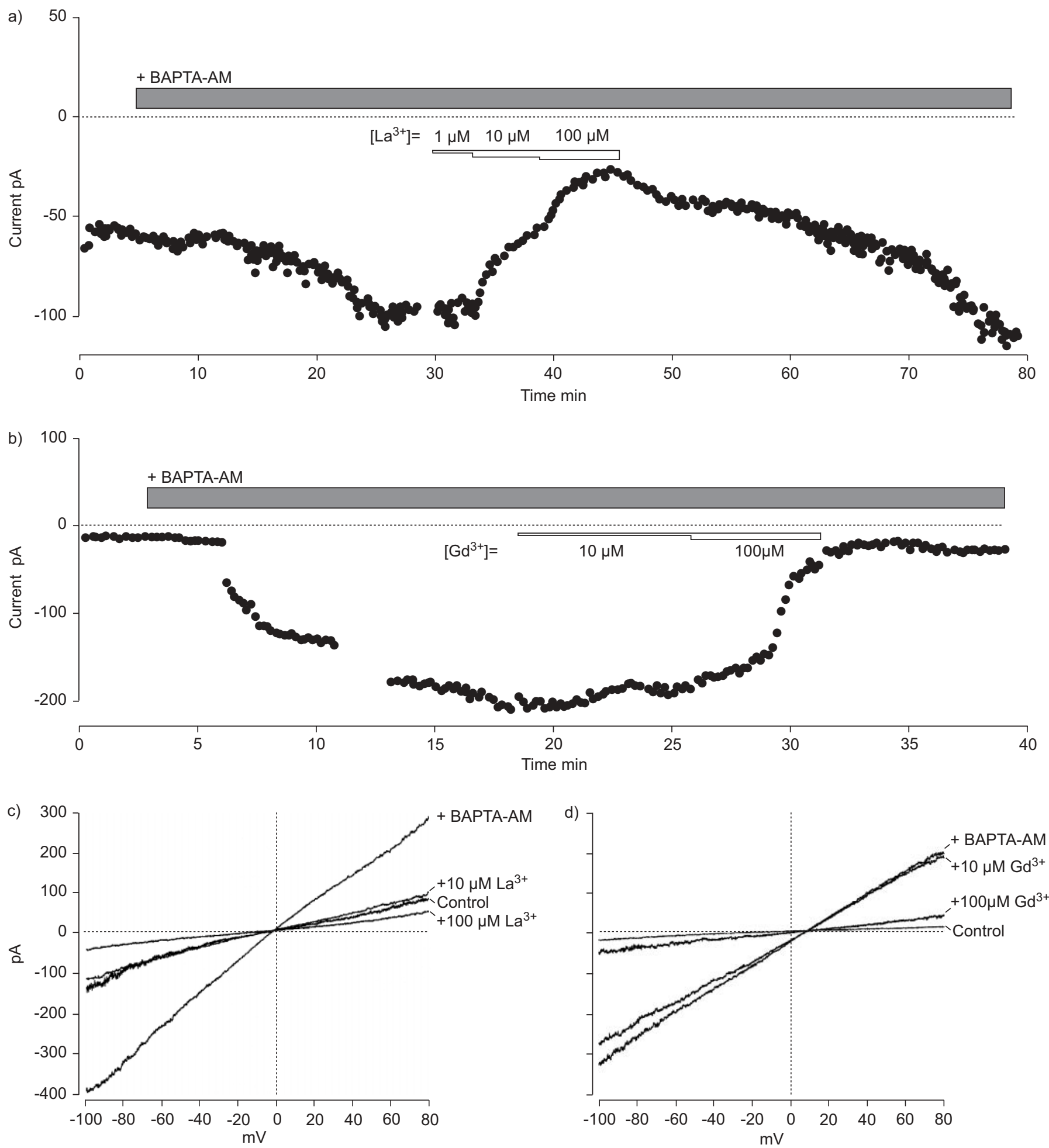

FIGURE 5. Block of BAPTA-AM-evoked whole-cell current by $\mathrm{La}^{3+}$ and $\mathrm{Gd}^{3+}$. Time course of inhibition of BAPTA-AM-evoked ( $\left.\square\right)$ membrane current by a) La ${ }^{3+}$ or b) Gd ${ }^{3+}$ in two separate cells. The amplitude of inward membrane currents elicited by voltage stepping cells to $-60 \mathrm{mV}$ at 10 -s intervals is shown ( $)$. Representative traces of membrane currents studied using voltage ramps in two separate cells. c) $\mathrm{La}^{3+}$ and d) $\mathrm{Gd}^{3+}$ were added to the bathing solution following activation of membrane current by 10 $\mu$ M BAPTA-AM. $\cdots: 0$.

across a range of physiologically relevant membrane potentials (e.g. -60 to $-30 \mathrm{mV}$ ). A large portion of the baseline and BAPTA-AM-evoked NSCC currents in the present study were also dependent upon extracellular $\mathrm{Na}^{+}$(fig. 4). These channels are also known to conduct $\mathrm{Ca}^{2+}$. Although one estimate found this to comprise only $14 \%$ of the overall current, it is sufficient 
a)

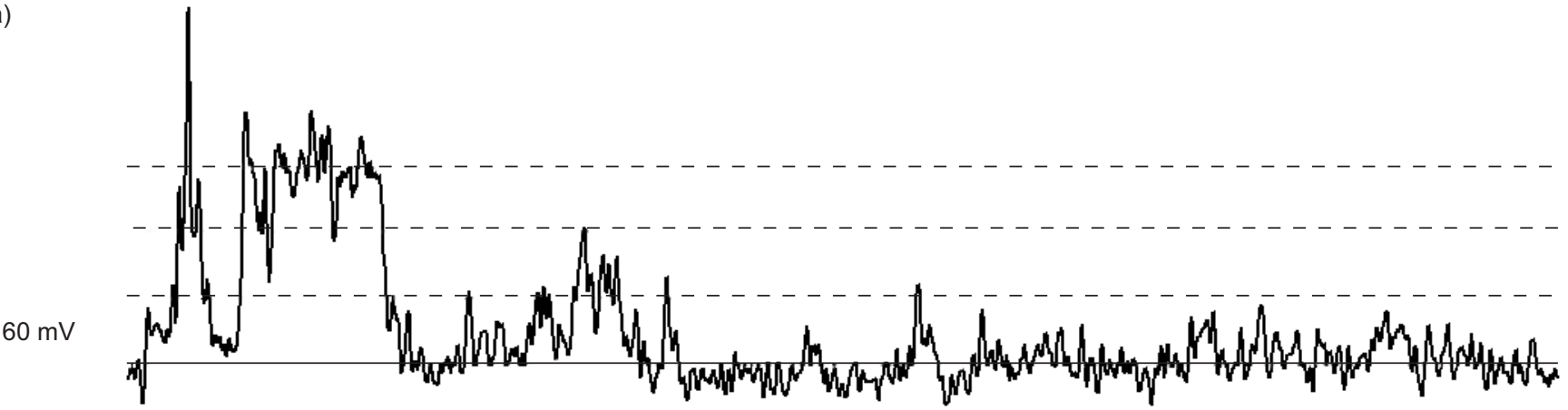

$0 \mathrm{mV}$

$-60 \mathrm{mV}$

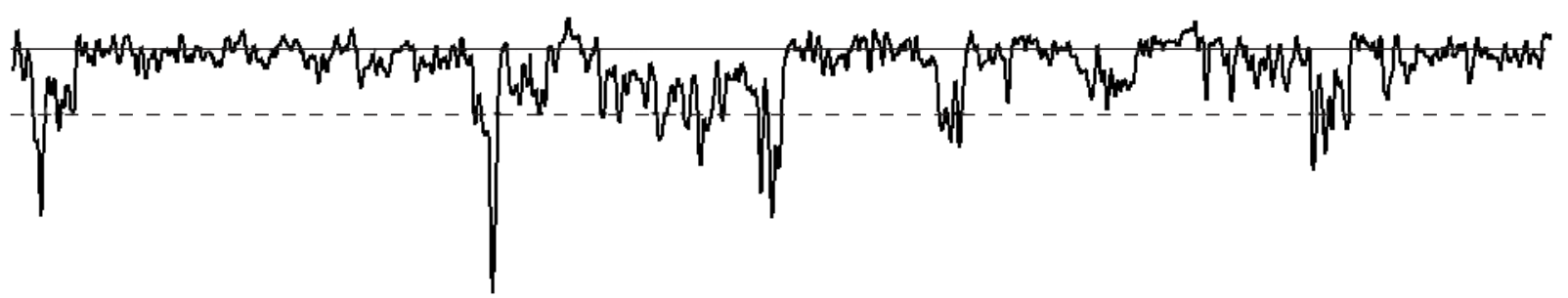

$-100 \mathrm{mV}$
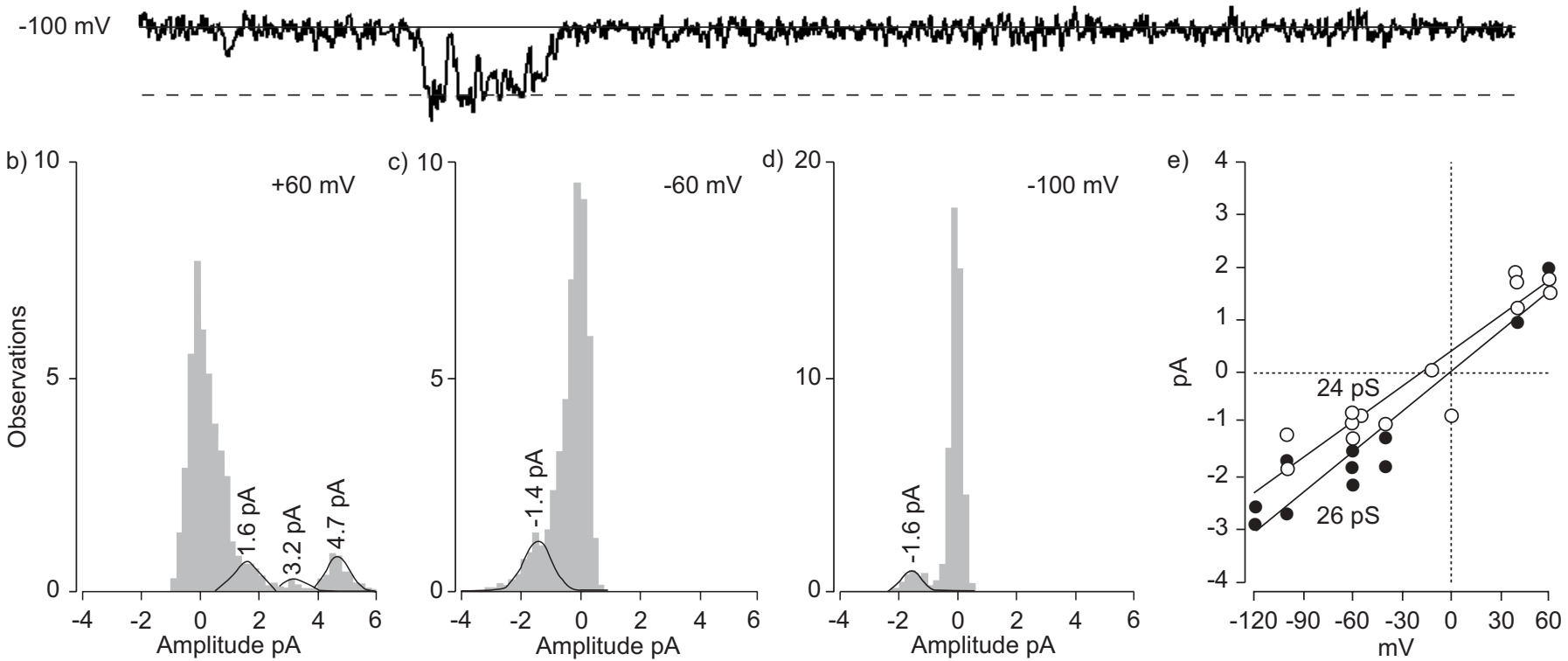

FIGURE 6. Properties of spontaneous unitary nonselective cation channel events. a) Representative traces of spontaneous single channel currents observed in a cellattached patch (126 mM NaCl 2 electrode) at different potentials. —-: closed channel state; - - -: predicted open states. All-points histograms for the data presented in (a) at b) $60 \mathrm{mV}$, c) -60 mV and d) $-100 \mathrm{mV}$. e) Mean current-voltage plots for spontaneous unitary channel currents studied with pipettes containing $126 \mathrm{mM} \mathrm{NaCl}$ ( $70 \mathrm{mM} \mathrm{CaCl}_{2}(O ; n=4) . \cdots \cdot 0$.

to maintain a modest yet sustained elevation of $\left[\mathrm{Ca}^{2+}\right] i[2,6]$. Others have demonstrated a constitutively active, nifedipineinsensitive $\mathrm{Ca}^{2+}$ influx pathway in bovine TSM, which is speculated to contribute to a resting $\left[\mathrm{Ca}^{2+}\right] i$ around $100-150 \mathrm{nM}$ $[14,20]$. CPA enhances $\mathrm{Ca}^{2+}$ entry in several other ASM preparations presumably through activation of $\mathrm{Ca}^{2+}$-permeable NSCCs $[10,15,16,24]$. Basal NSCC currents have also been described in isolated smooth muscle cells from rabbit portal vein [25], ear artery [26] and coronary artery [22] as well as rat pulmonary artery [27].

The signalling pathway underlying activation of the storeoperated NSCC currents is unclear. In the present study, Gprotein coupled receptor signalling was not necessary for 

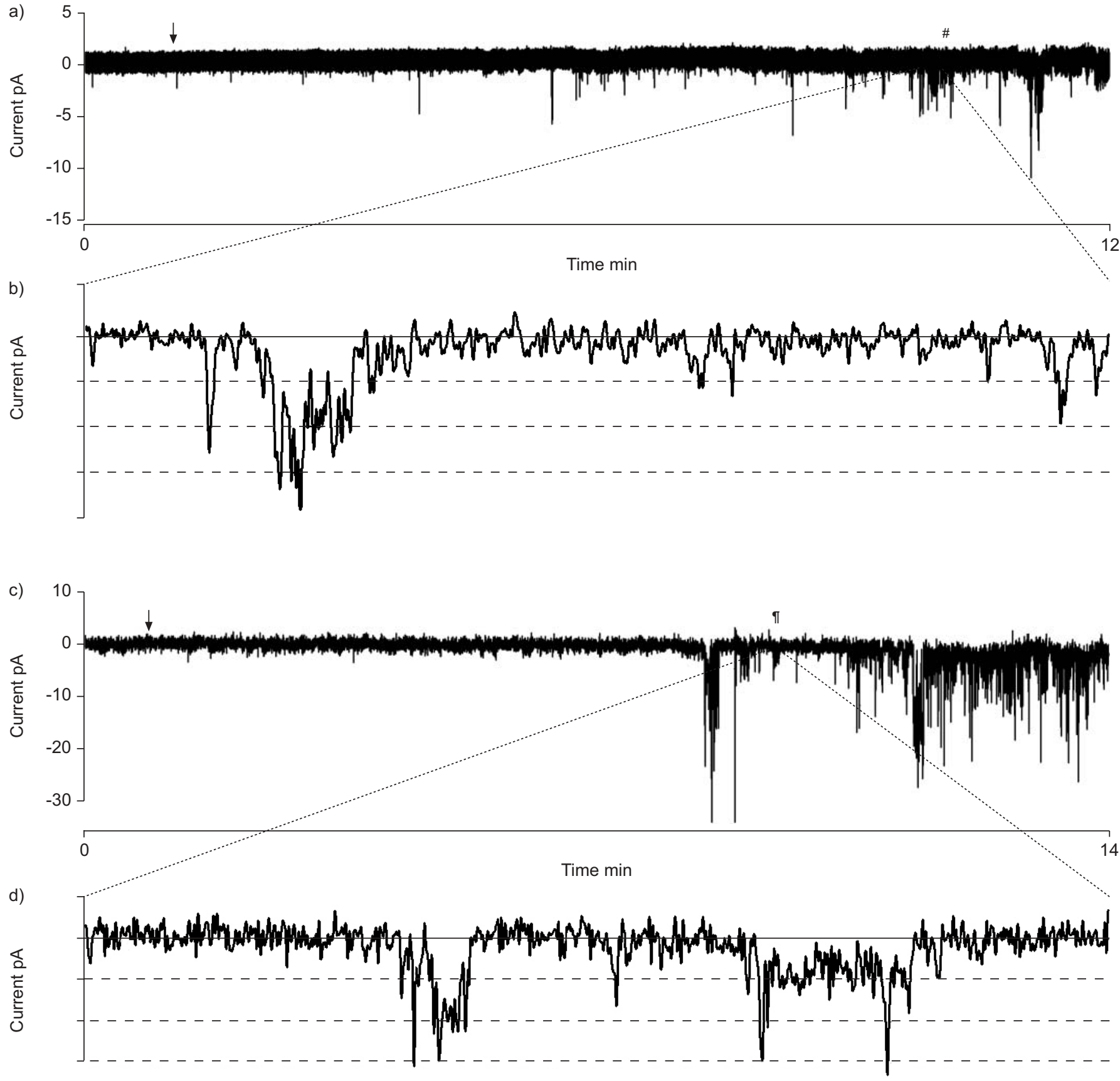

FIGURE 7. Properties of cyclopiazonic acid (CPA) and BAPTA-AM-evoked single channel currents. Representative traces of single channel membrane currents induced by bath application (arrow) of $10 \mu \mathrm{M}$ a) CPA or c) BAPTA-AM at a transmembrane potential of -60 mV. The $500 \mathrm{~ms}$ portions (", ") of recordings are expanded in b) and d) for CPA and BAPTA-AM, respectively. — : closed channel state; - - -: predicted open channel states. Pipettes contained $70 \mathrm{mM} \mathrm{CaCl} 2(\mathrm{a}, \mathrm{b}) \mathrm{and} 126 \mathrm{mM} \mathrm{NaCl}(\mathrm{c}, \mathrm{d})$.

NSCC activation, since treatment with BAPTA-AM or CPA alone was sufficient, although the possibility that this current may be regulated through diacylglycerol-protein kinase Cdependent mechanisms as demonstrated in vascular smooth muscle [28] cannot be ruled out. Also, although $\mathrm{Ca}^{2+}$ dependent facilitation of NSCC currents has been described in equine $[2,6]$ and porcine [18] TSM, the possibility that this channel was merely regulated by $\mathrm{Ca}^{2+}$ or $\mathrm{Ca}^{2+}$-dependent mechanisms is unlikely, since CPA evokes a transient increase in $\left[\mathrm{Ca}^{2+}\right] i[7]$ whereas BAPTA-AM suppresses $\left[\mathrm{Ca}^{2+}\right] i$.
In rabbit portal vein myocytes, spontaneous and store depletion-activated single channel events exhibit identical properties including unitary conductance, Er and mean open times, suggesting that a similar channel underlies both currents [25]. To determine if a similar mechanism operates in ASM, on-cell measurements of single channel currents were conducted both prior to and during passive store depletion with either CPA or BAPTA-AM. In all cell-attached patches examined, there was evidence of spontaneous single channel activity ( $\sim 44 \%$ exhibiting robust activity), which was 

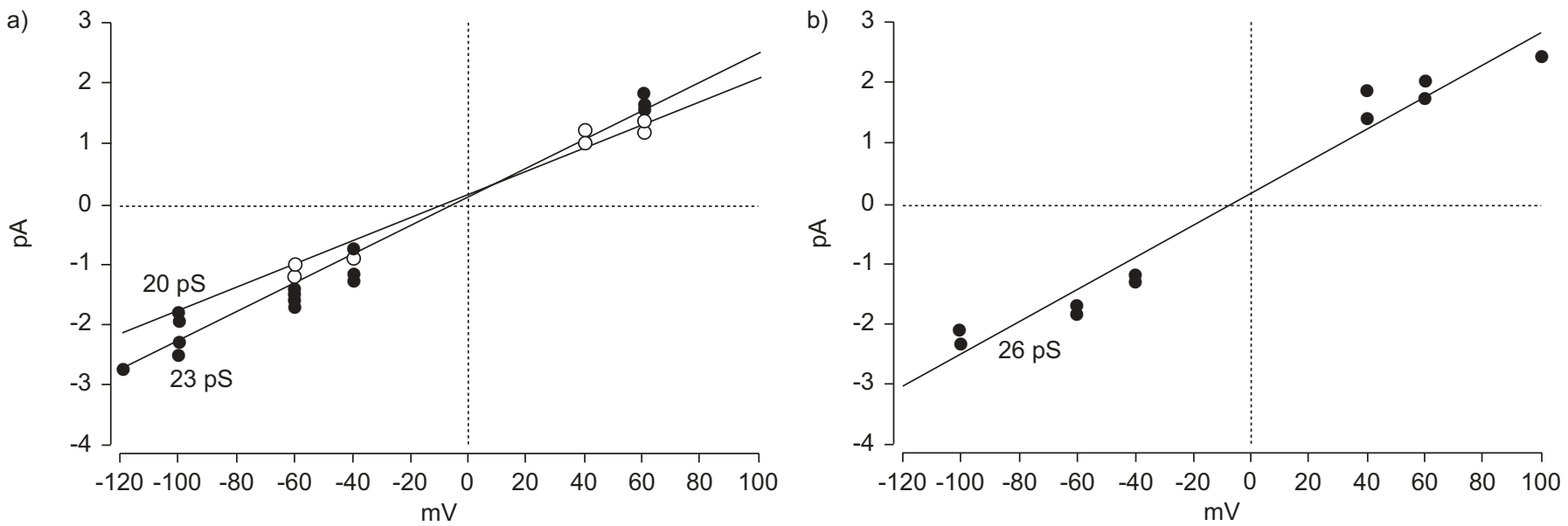

FIGURE 8. Mean current-voltage plots for a) cyclopiazonic acid (CPA) and b) BAPTA-AM-evoked unitary channel currents measured with pipettes containing 126 mM $\mathrm{NaCl}$

- $n=7$ and $n=4$ for CPA and BAPTA-AM, respectively) or $70 \mathrm{mM} \mathrm{CaCl} 2(O ; n=3)$.

attributed to a NSCC, given that the conductance was permeable to $\mathrm{Na}^{+}$and $\mathrm{Ca}^{2+}$ and that membrane currents through $\mathrm{Ca}^{2+}$-regulated $\mathrm{Cl}^{-}$channels, voltage-operated $\mathrm{K}^{+}$ channels, $\mathrm{Ca}^{2+}$-regulated $\mathrm{K}^{+}$channels and voltage-operated $\mathrm{Ca}^{2+}$ channels were eliminated by experimental design. Application of CPA or BAPTA-AM greatly increased the frequency and number of unitary channel events observed; single channel analysis revealed this to be mediated by a unitary conductance of $\sim 25 \mathrm{pS}$. The lanthanides $\mathrm{Gd}^{3+}$ and $\mathrm{La}^{3+}$ inhibit CPA-activated membrane currents and/or CCE in several tissues [16, 21,27]. In the present study, application of 10 and $100 \mu \mathrm{M} \mathrm{La}^{3+}$ reversibly inhibited the BAPTA-AMevoked current in a dose-dependent manner. This current was also found to be largely resistant to $10 \mu \mathrm{M} \mathrm{Gd}^{3+}$, although $100 \mu \mathrm{M} \mathrm{Gd}^{3+}$ caused a marked reduction of $\sim 80 \%$. In contrast to $\mathrm{La}^{3+}$, the inhibitory effect required several minutes to develop fully and was irreversible. It has been similarly found that extracellular $\mathrm{Gd}^{3+}$ irreversibly blocks TRP3 currents in Chinese hamster ovary cells with a late onset [29]; the authors of that study speculated that the kinetics of inhibition by $\mathrm{Gd}^{3+}$ in intact cells relied upon the uptake and extrusion rate of this cation, since the median effective concentration (EC50) was lower and the rate of inhibition faster when $\mathrm{Gd}^{3+}$ was applied to the cytosolic face of the channel.

While others have shown that a 25 pS NSCC with similar properties (i.e., unitary conductance and sensitivity to $1 \mathrm{mM}$ $\mathrm{La}^{3+}, \mathrm{Gd}^{3+}$ and $100 \mu \mathrm{M}$ SKF 96365) is activated by leukotrienes in isolated human BSM, its role in mediating CCE was not specifically examined [3]. As such, the current finding that an $\sim 25 \mathrm{pS}$ channel underlies CPA- and BAPTA-AM-evoked NSCC currents in bovine TSMs is novel. The magnitude of the conductance described herein is 10-fold greater than that reported for store depletion-activated NSCCs in vascular smooth muscle cells $[25,30,31]$; the possibility that small conductance NSCCs were hidden within the noise inherent in the recordings cannot be ruled out. Involvement of this NSCC explains why the $\mathrm{Ca}^{2+}$ entry induced by CPA was resistant to nifedipine (fig. 6). BAZAN-PERKINS et al. [20] found that the rate of $\mathrm{Ca}^{2+}$ entry in bovine TSM cells with depleted SR $\mathrm{Ca}^{2+}$ stores was resistant to D600. Likewise, in guinea pig TSM, depletion of SR $\mathrm{Ca}^{2+}$ with the SERCA inhibitor thapsigargin induced a rise in $\left[\mathrm{Ca}^{2+}\right] i$ and a contraction that was dependent upon extracellular $\mathrm{Ca}^{2+}$, was inhibited by $\mathrm{Ni}^{2+}$ and SKF 96365 but not nifedipine [15], and similar results have been observed in rat basolateral membrnae upon depletion of acetylcholine-sensitive stores [1].

In summary, the present authors conclude that loading of bovine tracheal smooth muscle cells with BAPTA-AM (in order to reduce cytosolic $\mathrm{Ca}^{2+}$ concentration and thereby deplete the store) augments a basal, $\mathrm{Ca}^{2+}$-permeable nonselective cation conductance that is both $\mathrm{Gd}^{3+}$ - and $\mathrm{La}^{3+}$-sensitive. In addition, the present findings indicate that an $\sim 25 \mathrm{pS}$ nonselective cation channel underlies both basal, cyclopiazonic acid- and BAPTA-AM-evoked membrane currents in this tissue. Furthermore, the data suggest that nonselective cation channels contribute to the regulation of cytosolic $\mathrm{Ca}^{2+}$ concentration and sarcoplasmic reticulum refilling and are likely to be responsible for the capacitative $\mathrm{Ca}^{2+}$ entry observed in airway smooth muscle.

\section{REFERENCES}

1 Sweeney M, McDaniel SS, Platoshyn O, et al. Role of capacitative $\mathrm{Ca}^{2+}$ entry in bronchial contraction and remodeling. J Appl Physiol 2002; 92: 1594-602.

2 Wang YX, Kotlikoff MI. Signalling pathway for histamine activation of nonselective cation channels in equine tracheal myocytes. J Physiol 2000; 523: 131-138.

3 Snetkov VA, Hapgood KJ, McVicker CG, Lee TH, Ward JP. Mechanisms of leukotriene D4-induced constriction in human small bronchioles. Br J Pharmacol 2001; 133: 243-252.

4 Janssen LJ, Wattie J, Lu-Chao H, Tazzeo T. Muscarinic excitation-contraction coupling mechanisms in tracheal and bronchial smooth muscles. J Appl Physiol 2001; 91: 1142-1151.

5 Janssen LJ, Sims SM. Emptying and refilling of $\mathrm{Ca}^{2+}$ store in tracheal myocytes as indicated by ach-evoked currents and contraction. Am.J.Physiol 1993; 265: C877-C886. 
6 Fleischmann BK, Wang YX, Kotlikoff MI. Muscarinic activation and calcium permeation of nonselective cation currents in airway myocytes. Am J Physiol 1997; 272: C341-C349.

7 Helli PB, Pertens E, Janssen LJ. Cyclopiazonic acid activates a $\mathrm{Ca}^{2+}$-permeable, nonselective cation conductance in porcine and bovine tracheal smooth muscle. J Appl Physiol 2005; 99: 1759-1768.

8 Hirota S, Pertens E, Janssen LJ. The reverse mode of the $\mathrm{Na}^{+} / \mathrm{Ca}^{2+}$ exchanger provides a source of $\mathrm{Ca}^{2+}$ for store refilling following agonist-induced $\mathrm{Ca}^{2+}$ mobilization. Am J Physiol Lung Cell Mol Physiol 2007; 292: L438-L447.

9 Dai JM, Kuo KH, Leo JM, van Breemen C, Lee $\mathrm{CH}$. Mechanism of ACh-induced asynchronous calcium waves and tonic contraction in porcine tracheal muscle bundle. Am J Physiol Lung Cell Mol Physiol 2006; 290: L459-L469.

10 White TA, Xue A, Chini EN, Thompson M, Sieck GC, Wylam ME. Role of transient receptor potential C3 in TNF- $\alpha$-enhanced calcium influx in human airway myocytes. Am J Respir Cell Mol Biol 2006; 35: 243-251.

11 Freichel M, Vennekens R, Olausson J, et al. Functional role of TRPC proteins in native systems: implications from knockout and knock-down studies. J Physiol 2005; 567: 59-66.

12 Albert AP, Pucovsky V, Prestwich SA, Large WA. TRPC3 properties of a native constitutively active $\mathrm{Ca}^{2+}$-permeable cation channel in rabbit ear artery myocytes. J Physiol 2006; 571: 361-369.

13 Peel SE, Liu B, Hall IP. A key role for STIM1 in store operated calcium channel activation in airway smooth muscle. Respir Res 2006; 7: 119.

14 Ethier MF, Yamaguchi H, Madison JM. Effects of cyclopiazonic acid on cytosolic calcium in bovine airway smooth muscle cells. Am J Physiol Lung Cell Mol Physiol 2001; 281: L126-L133.

15 Ito S, Kume H, Yamaki K, et al. Regulation of capacitative and noncapacitative receptor-operated $\mathrm{Ca}^{2+}$ entry by $\rho-$ kinase in tracheal smooth muscle. Am J Respir Cell Mol Biol 2002; 26: 491-498.

16 Ay B, Prakash YS, Pabelick CM, Sieck GC. Store-operated $\mathrm{Ca}^{2+}$ entry in porcine airway smooth muscle. Am J Physiol Lung Cell Mol Physiol 2004; 286: L909-L917.

17 Pabelick CM, Ay B, Prakash YS, Sieck GC. Effects of volatile anesthetics on store-operated $\mathrm{Ca}^{2+}$ influx in airway smooth muscle. Anesthesiology 2004; 101: 373-380.

18 Yamashita T, Kokubun S. Nonselective cationic currents activated by acetylcholine in swine tracheal smooth muscle cells. Can J Physiol Pharmacol 1999; 77: 796-805.
19 Tazzeo T, Zhang Y, Keshavjee S, Janssen LJ. Ryanodine receptors decant internal $\mathrm{Ca}^{2+}$ store in human and bovine airway smooth muscle. Eur Respir J 2008; 32: 275-284.

20 Bazan-Perkins B, Flores-Soto E, Barajas-Lopez C, Montano LM. Role of sarcoplasmic reticulum $\mathrm{Ca}^{2+}$ content in $\mathrm{Ca}^{2+}$ entry of bovine airway smooth muscle cells. Naunyn Schmiedebergs Arch Pharmacol 2003; 368: 277-283.

21 Flemming R, Xu SZ, Beech DJ. Pharmacological profile of store-operated channels in cerebral arteriolar smooth muscle cells. British Journal of Pharmacology 2003; 139: 955.

22 Terasawa K, Nakajima T, Iida H, et al. Nonselective cation currents regulate membrane potential of rabbit coronary arterial cell: modulation by lysophosphatidylcholine. Circulation 2002; 106: 3111-119.

23 Wilson SM, Mason HS, Smith GD, et al. Comparative capacitative calcium entry mechanisms in canine pulmonary and renal arterial smooth muscle cells. J Physiol 2002; 543: 917-931.

24 Ay B, Iyanoye A, Sieck GC, Prakash YS, Pabelick CM. Cyclic nucleotide regulation of store-operated $\mathrm{Ca}^{2+}$ influx in airway smooth muscle. Am J Physiol Lung Cell Mol.Physiol 2006; 290: L278-L283.

25 Albert AP, Large WA. A $\mathrm{Ca}^{2+}$-permeable non-selective cation channel activated by depletion of internal $\mathrm{Ca}^{2+}$ stores in single rabbit portal vein myocytes. J Physiol 2002; 538: 717-728.

26 Albert AP, Piper AS, Large WA. Properties of a constitutively active $\mathrm{Ca}^{2+}$-permeable non-selective cation channel in rabbit ear artery myocytes. J Physiol 2003; 549: 143-156.

$27 \mathrm{Ng}$ LC, Gurney AM. Store-operated channels mediate $\mathrm{Ca}^{2+}$ influx and contraction in rat pulmonary artery. Circ Res 2001; 89: 923-929.

28 Albert AP, Large WA. Activation of store-operated channels by noradrenaline via protein kinase $\mathrm{c}$ in rabbit portal vein myocytes. J Physiol 2002; 544: 113-125.

29 Halaszovich CR, Zitt C, Jungling E, Luckhoff A. Inhibition of TRP3 channels by lanthanides. block from the cytosolic side of the plasma membrane. J Biol Chem 2000; 275: 37423-37428.

30 Trepakova ES, Gericke M, Hirakawa Y, Weisbrod RM, Cohen RA, Bolotina VM. Properties of a native cation channel activated by $\mathrm{ca}^{2+}$ store depletion in vascular smooth muscle cells. J Biol Chem 2001; 276: 7782-7790.

31 Golovina VA, Platoshyn O, Bailey CL, et al. Upregulated TRP and enhanced capacitative $\mathrm{Ca}^{2+}$ entry in human pulmonary artery myocytes during proliferation. Am J Physiol Heart Circ Physiol 2001; 280: H746-H755. 